\title{
PORIN KULTTUURISÄÄDÖN TOTUUS SUOMESTA - YRITYS KUVITELLA KANSALLISVALTION ESITTÄMISTÄ TOISIN
}

Suomessa on vietetty kohta vuoden verran satavuotisjuhlaa. Lähes jokainen kynnelle kykenevä taiteilija on valjastettu erilaisiin kansallismielisiin hankkeisiin, joista toiset ovat olleet onnistuneempia kuin toiset, ja toiset kriittisempiä kuin toiset. Porin kulttuurisäädön virallisen Suomi 100 -hankkeen ulkopuolella toteutettu Totuus Suomesta -projekti lukeutunee jälkimmäisiin, ainakin tällaisena sitä on ulkoapäin tarkasteltu. Näin se on myös onnistunut tuomaan näkyville rakenteita ja toimintatapoja, jotka juhlahumussa haluttaisiin mieluummin hymistellä unohduksiin.

Porin kulttuurisäätö (Anna Jensen, Anni Venäläinen ja Eliisa Suvanto) toteutti kesällä Suomi 100 -juhlavuoden esiin nostamia kysymyksiä tarkastelevan kokonaisuuden, johon kuului kaksi näyttelyä ja julkaisu. Mukaan kutsuttiin yli sata toimijaa tieteen ja taiteen aloilta Suomesta ja ulkomailta. Ensimmäinen näyttely järjestettiin Helsingissä Kallio Kunsthallessa, ja avajaisten yhteydessä juhlittiin myös katalogin julkaisua. Toinen näyttely järjestettiin heinäkuussa Porissa, jonne rakennetussa väliaikaisessa näyttelytilassa esiteltiin sadan tekijän näkemykset Suomesta vuonna 2017.

Kallio Kunsthallen näyttelyosuuteen koottiin työryhmä taiteilijoita ja tutkijoita, joita yhdisti aiempi työskentely toiseuden historiaa ja historiallisia representaatioita koskevien kysymysten parissa. Historioitsija Miika Tervonen, joka on aiemmin tutkinut muun muassa nationalismia ja sitä miten käsitys suomalaisuudesta on synnytetty, keräsi näyttelyyn materiaalia tavoista, joilla toinen maailmansota elää suomalaisessa (populaari)kulttuurissa, sekä käsitteli sitä luentomuotoisessa teoksessaan $H_{-}$ ristimonologi. Nynnyt, eli kuraattoriduo Hanna Ohtonen ja Selinä Väliheikki nostavat työskentelyssään sukupuolen keskeiseksi kysymykseksi. Monumenttien sukupuolittuneisuuden tutkiminen on olennaista suhteessa kansalliseen identiteettiin, sen rakentamiseen ja tähän prosessiin kytkeytyviin julkisiin teoksiin. Kunsthallessa duo järjesti Heikki Häiväojan (1996) Sodanajan naisen muistomerkkiä tutkivan työpajan ja toi näyttelytilaan muistomerkkiin liittyvää tekstuaalista aineistoa. Honkasalo - Niemi - Virtanen kollektiivi oli käsitellyt toiseuden historiaa jo kesällä 2016 Seurasaaren Finnish Landscapes näyttelyssä esityksellä, joka yhdisteli todellista ja fiktiivistä historiaa marginaaliin suljettujen hahmojen näkökulmista. Kunsthalleen he toivat teoksen, jossa fakta ja fiktio sekoittuivat tuoksun muodossa. Erno-Erik Raitanen on teoksissaan tulkinnut uudelleen suomalaisen taiteen ikonisia tuotoksia Taistelevista metsoista Finlandiaan ja toisaalta tutkinut viime vuosien uusnationalistista liikettä. Totuus Suomesta -näyttelyn teoksessaan Raitanen keräsi dataa Helsingin julkisista teoksista tuoden näkyville räikeän eron sukupuolten välillä sekä julkisten teosten tekijöinä että aiheena.

Porin näyttelyyn ja katalogiin kutsuttiin sata tekijää, joille annettiin teeman käsittelytavan ja näkökulman suhteen vapaat kädet, mutta toteutuksen muodoksi määriteltiin, että teos/kontribuutio pitää esittää A4-formaatissa. Tekijöiden toimittamista pdf-tiedostoista tehtiin näyttelyvedokset Poriin, ja ne julkais- 
tiin myös katalogissa. Porin kulttuurisäätö suunnitteli ja rakennutti näyttelyä varten väliaikaisen näyttelytilan kaupungin keskustaan Kokemäenjoen rannalle, vilkkaan kulkuväylän varrella sijaitsevaan Puuvillan puistoon. $\mathrm{Mu}-$ kaan kutsuttu taiteilija- ja tutkijajoukko koostui sekä suomalaisista että kansainvälisistä tekijöistä, joita kollektiivin mielestä yhdisti ennakkoluulottomuus, rohkeus ja kyky esittää asioita toisin. Samalla Totuus Suomesta tarkasteli näyttelykäytäntöjä uudesta näkökulmasta ja testasi näyttelyilmaisun rajoja. Toteutettu julkaisu jää pysyväksi dokumentiksi näyttelystä tuoden esiin ja tallentaen katsauksen siitä, miten Suomi koetaan vuonna 2017 ja millaisilla välineillä ja muodoilla sitä tarkastellaan. Totuus Suomesta -projektin välityksellä Porin kulttuurisäätö -kollektiivi tutki sitä, miten Suomi nähdään vuonna 2017, miten Suomeen liittyvät mielikuvat ovat historiallisesti rakentuneet, sekä sitä, onko kulttuuriseen ajatteluun mahdollista ylipäätään päästä käsiksi kulttuurin sisältä käsin.

Alun perin osana Suomi 100 -hanketta aloitettu Totuus Suomesta -projekti on ollut melkoinen matka. Irottauduimme varhaisessa vaiheessa virallisesta hankkeesta, koska koimme, että se ei edusta Suomea, jonka tunnemme ja koemme omaksemme. Hanke ylläpitää keinotekoisesti tuotettua kuvaa yhtenäisestä Suomesta, jonka ydinolemuksen muodostavat lumiset maisemat, koivut, villasukat ja saunat (joissa saunovat valkoiset virheettömät suomalaiset). Lisäksi hankkeen henkenä tuntui olevan kaikenlaisten projektien valjastaminen hankkeen nimikkeen ja visuaalisen ilmeen alle laadusta välittämättä. On myös ongelmallista, ettei virallisen hankkeen puitteissa ole riittävästi huolehdittu tekijöille tarjotusta tuesta tai tehdystä työstä maksetuista korvauksista. Ennen kaikkea emme kokeneet, että Suomi 100 on kaikille avoin yhteinen projekti, vaan jotakin, jossa olennaista on ollut"aidon" ja "oikean" suomalaisen identiteetin ylläpitäminen.

Virallisen hankkeen edustama puhtaanvalkoinen sauna-Suomi tuntui meille fiktiivi- seltä ja vieraalta, ja koimme tämän narratiivin pönkittämisen sijaan olennaisemmaksi sen purkamisen.

Projektillamme haluamme osallistua keskusteluun, jota nyt käydään siitä, miten kuvaa suomalaisuudesta on rakennettu ja miten taidetta ja visuaalista materiaalia on käytetty välineenä tässä rakennustyössä. Tavoitteena on osoittaa luonnollistettujen struktuurien historia ja päästä eroon marginalisoivista käytännöistä, joita kulttuurin avulla on oikeutettu.

Kulttuurin ja sitä vuosikymmenien ajan rakentaneiden teosten ja tekojen käsitteleminen kulttuurin sisältä käsin on vähintäänkin hankala, ellei mahdoton tehtävä. Onko luonnollistetuista ajatusrakennelmista ja oletuksista mahdollista päästä eroon, ja jos on, minkälaista ajattelua tulee tilalle? Entä miten tällaista mahdollisesti uudenlaista ajattelun ja tekemisen tapaa voi välittää yleisölle niin, että se avautuu (edes jollain tavalla, sillä tavoitteena ei ole popularisoida taidetta ja tutkimusta, eikä taiteen "ymmärtäminen" ole ylipäätään meille kiinnostava lähtökohta) tai tulee jaettavaksi myös niiden kesken, jotka eivät ole sisällä prosessissa.

Projektin avannutta Kallio Kunsthallen näyttelyä, ja sitä kautta koko projektin merkitystä ja siihen liittyviä laajoja kysymyksiä, työstettiin työryhmän kanssa lähes vuosi. Läpi talven käydyissä keskusteluissa, niin yhteisissä kokoontumisissa kuin näitä seuranneissa ajoittain kärkkäissä chattikeskusteluissakin, pohdittiin kysymyksenasettelua sekä muotoja, joilla aihetta voi lähestyä. Työryhmä on ollut keskeinen osa sitä, miten projektia on ajateltu ja mihin suuntaan se on edennyt. Se on ollut paikka testata mahdollisesti kummallisiakin ajatuksia sekä välittää ja hankkia uutta tietoa. Esille nousi ongelmia, jotka liittyvät isojen ja arkojen aiheiden käsittelyyn, sekä ylipäänsä sanallistamisen ongelmiin - kuinka ajatella ideologiaa, jos on sen sisällä ja sen läpäisemä? Vaikka kyseessä on vahvasti poliittinen aihe, halusimme välttää tekemisen, jossa muoto on alisteista alleviivatulle ja yksinkertaistetulle sanomalle. Halusimme käsitellä aihetta niin että 
se tarjoaa kosketuspintoja, mutta yksinkertaistamatta. Olennaista Totuus Suomesta -hankkeen kannalta on se, miten taide myös tuottaa merkityksiä ja miten tämän taiteen aktiivisen roolin sivuuttaminen voi olla vaarallista. Taiteen tekeminen on poliittinen teko, ja kaikki taide on poliittista. Se syntyy tietynlaisessa kulttuurissa ja maailmantilanteessa sekä ottaa siihen kantaa tahtoen tai tahtomattaan.

Pohtiessamme uudenlaisia muotoja, joilla lähestyä asiaa, kävimme läpi vaihtoehtoja täysin uudenlaisesta kielestä parodiaan, toisintoistamiseen, replikoihin ja sanan ja kuvan suhteen muuttamiseen. Haussa oli uudenlainen kaikille tasa-arvoisesti avoin keskustelu, mutta kuten esimerkiksi feministisestä traditiosta tuttu écriture féminine -käsite on osoittanut, täysin uusi kieli avaa mahdollisuuksia, mutta kumouksellista voimaa voi olla vaikea välittää suurelle yleisölle. Tällöin projekti jää helposti käsittämättömäksi ja vieraaksi. Halusimme pitää muodon lähestyttävänä ja saavutettavana. Ei niinkään ymmärrettävänä, koska taiteen ymmärtämiseen on yleensä rajattomasti tapoja ja uskomme kokemuksellisuuteen ennen ymmärrystä. Usein liian helposti rinnastettavat"uusi" ja "elitistinen" eivät välttämättä ole synonyymejä.

Näin ajateltuna ei pelkästään taiteen tekeminen, vaan myös taiteen muodon uudistaminen on poliittinen teko. Samoin poliittista on taiteen ja tutkimuksen rajojen rikkominen, tai se, että taiteen (ja tutkimuksen) vie ihmisten keskelle ja pakottaa yleisön katsomaan ja näkemään. Katsominen ja asioiden näkeminen ovat tottumiskysymyksiä, ja tottumus johtaa helposti ainakin jonkinasteiseen, mahdollisesti tiedostamattomaan, hyväksymiseen. Tervonen kirjoittaa Totuus Suomesta -julkaisussa "kansallisen katseen kohtaamisesta" ja siihen liittyvistä sokeista pisteistä: "Kasvamme jokapäiväisten vihjeiden kautta näkemään maailman kansallisen katseen kautta. Tämä katse redusoi monimutkaista todellisuutta; se essentialisoi, sulkee ulos ja asettaa vastakkain; ja tuottaa sokeita pisteitä ja muistinmenetyksiä." $(2017,12$.
Ravistelemalla näitä opittuja ja juurtuneita katsomisen tapoja taide voi pakottaa ajattelemaan uudestaan, muuttaa ajattelua, näkemistä ja rakenteita. Eri taiteenaloilla on erilaiset traditiot ja erilaiset tavat lähestyä ongelmallista kuvastoa. Siinä missä teatterissa jatkuva uudelleentulkinta esitys esitykseltä erilaisissa ympäristöissä on pakottanut kyseenalaistamaan tekstien tuottamat representaatiot, on monet mahdollisesti hyvinkin kyseenalaiset kuvataiteen teokset jätetty rauhaan. Suomalaiselle kulttuurille keskeisiä teoksia ei oikein edes saisi problematisoida, ja mikäli näin tapahtuu, jää se valitettavan usein kentän sisäiseksi keskusteluksi.

Keskusteluissamme pohdimme myös sitä, miten tietyt symbolit nousevat pahan merkkinä ylitse muiden. Törmäsimme keskustelussa jatkuvasti hakaristiin, ja totesimme tämän äärimmäisen pahuuden symbolin toimivan hyvänä esimerkkinä voimasta, jonka merkki voi saada ja joka eri tavoin samalla lukitsee keskustelua ja ajattelua."Pahuuden" käsite yksinkertaistuu, rajautuu koskemaan vain tiettyä aikaa, paikkaa ja tekijäjoukkoa, ja maailma mustavalkoistuu. Toisaalta esimerkiksi hakaristin toisintoistaminen ei välttämättä onnistu, vaan merkki voi osoittautua taiteilijaa vahvemmaksi. Olennaisin, eli hirmutekoja synnyttävät ja mahdollistavat rakenteet voivat jäädä piiloon. Kuten myös se, että sama pahuuden potentiaali voi löytyä kaikista ihmisistä. Helposti unohdetaan, että tällaiset hirmuteot eivät kuuluu menneisyyteen, vaan voivat tapahtua uudestaan, koska tahansa. Symboleitakin tulee uusia, ja vanhoja kierrätetään. Nykyään äärioikeisto on korvannut hakaristin osittain muilla symboleilla, mutta ei ryhmänä ole silti sen vähemmän vaarallinen.

Näyttelyn nimi, Totuus Suomesta, on paradoksi - ei ole olemassa yhtä totuutta, vaan ainoastaan erilaisia kokemuksia totuudesta. Yli sadan tekijän näkemyksistä muodostuva kaleidoskooppimainen kokonaisuus on yksi mahdollinen visio ajastamme, mutta erilaisia visioita on yhtä monta kuin ajattelijoitakin. 
Nimeä ja siihen sisältyvää vitsiä ei kuitenkaan kaikkialla ymmärretty, vaan se koettiin provokaatioksi. Näyttelyn sisältöön perehtymättä esimerkiksi Suomi-Areena teki projektin toteuttamisen Porin ydinkeskustassa mahdottomaksi ja kutsui mediassa hanketta"ilkeäksi" ja "Pori-kriittiseksi". Hanke ei ollut kumpaakaan, ja etenkin jälkimmäinen väite on suorastaan naurettava. Koko toimintahistoriamme ajan olemme olleet hyvin tietoisia siitä, miten Porin kaupungin positiivinen taidepolitiikka mahdollistaa toimintaamme erityisellä tavalla. Vastaava ei mielestämme olisi mahdollista esimerkiksi pääkaupunkiseudulla. Tätä politiikkaa ja päättäjien ja kaupungin virkamiesten avoimuutta erilaisille kokeellisille hankkeille olemme myös toistuvasti mediassa kiitelleet. Samoin olemme kukin tahoillamme opetustilanteissa tai muissa kaupungeissa työskennellessämme tuoneet esiin Porissa toimimisen etuja. Erityisen outoa oli, että Suomi-Areenalla todella on tapahtumaaikanaan valta päättää ja laskuttaa haluamansa summa kaupunkitilan käytöstä Porissa, mutta ei velvollisuutta esittää mitään dokumenttia siitä, mihin valta perustuu ja mitä alueita SuomiAreenan hallinnan piiriin kuuluu.

Juhlavuoden aikana on tullut liiankin selväksi, että sellaisille aiheille, jotka eivät ole mahtuneet viralliseen ohjelmaan, on tarvetta. Hankkeen kautta on kuitenkin nousemassa esiin yksi äärimmäisen epämiellyttävä totuus ylitse muiden: Suomen identiteetin oletetaan edelleen olevan niin hauras, että sitä on suojeltava näkökulmien moninaisuudelta. Kaikkien odotetaan liittyvän yhteisiin talkoisiin, joilla ylläpidetään ja vahvistetaan Suomesta sitä kuvaa, joka varsin väkivaltaisesti ja keinotekoisesti on vuosikymmenten kuluessa luotu. Tämä ei ole minun Suomeni, eikä se maa jossa olen kasvanut.

Suomi on valtava maa täynnä erilaisia kulttuureja, jotka eivät ole tässä tasa-arvoisuudesta tunnetussa maassa saaneet tasa-arvoista kohtelua. Erilaisia maisemia, murteita, kieliä ja ruokia. Suomi on kansainvälinen, haluttiin tai ei.Ja on aina ollut, asia joka etenkin viime aikoina on aktiivisesti haluttu unohtaa. Haluamme tuoda tämän esiin ja nostaa näkyville tekniikoita,joilla mielikuviemme Suomi on luotu ja joilla sitä eri tavoin yhä ylläpidetään ja voimistetaan. Benedict Anderson ehdottaa kansakunnan määritelmäksi seuraavaa: kansakunnat ovat "kuviteltuja poliittisia yhteisöjä - ja ne on kuviteltu sekä sisäisesti rajallisiksi että täysivaltaisiksi” (2007, 39). Projektissamme halusimme tutkia toisinkuvittelemisen mahdollisuuksia. Ainakin onnistuimme herättämään keskustelua ja tuomaan esiin asioita, jotka olisivat muuten jääneet näkymättömiksi, ja sitä kautta vähintään yksi projektin tavoitteista toteutui.

Totuus Suomesta -projekti on ollut yritys tutkia nykyhetkeä, mutta myös taustaa, jolle nykypäivän tapahtumat rakentuvat. Samalla olemme suunnanneet katseen tulevaisuuteen. Taiteella on aina ollut kyky ennustaa tulevaa, joten luomme oman kristallipallon. Riskinä on, että se näyttää mitä itse haluamme, olemmehan valinneet taiteilijat sekä muodon jossa teokset esitetään. Toisaalta projektimme on ollut myös avain keskusteluun, ja sellaisena koemme sen onnistuneeksi. Näyttelyissä kävi valtava joukko ihmisiä, jotka kokivat aiheen tärkeäksi ja tarttuivat mahdollisuuteen keskustella siitä. Näyttelyt myös tarjosivat mahdollisuuden pohjustaa seuraavaa näyttelyä, jota varten olemme toteuttaneet kyselyn siitä, minkälaista taidetta toivotaan nähtäville vuonna 2018 tai halutaanko taidetta ylipäänsä nähdä. Vastaukset ilahduttivat: taidetta halutaan nähdä, sitä toivotaan osaksi arkea, taiteen toivotaan olevan monimediaista ja kriittistä.

\section{- ANNA JENSEN}

\section{KIRJALLISUUS}

Anderson, Benedict (2007) Kuvitellut yhteisöt. Nationalismin alkuperän ja leviämisen tarkastelua. Suom. Joel Kuortti. Vastapaino.

Tervonen, Miika (2017) Kansallisen katseen kohtaamisesta. Totuus Suomesta -julkaisu. Toim. Anna Jensen, Anni Venäläinen ja Eliisa Suvanto. 